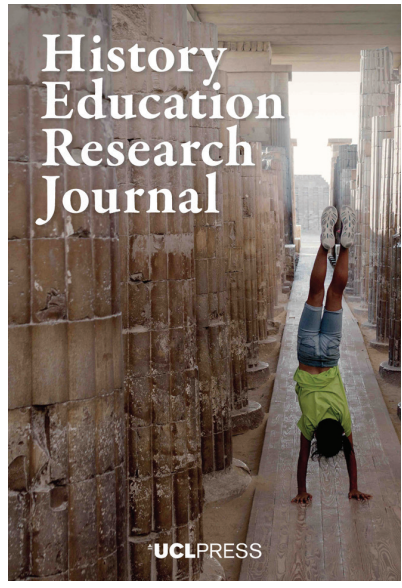

${ }^{\wedge}$ UCLPRESS

\title{
HISTORY EDUCATION RESEARCH JOURNAL
}

ISSN 2631-9713 (Online)

Journal homepage:

https://www.uclpress.co.uk/pages/history-educationresearch-journal

\section{The educational power of heritage sites}

\author{
Martin Stolare (D), David Ludvigsson (iD and Cecilia Trenter (iD
}

\section{How to cite this article}

Stolare, M., Ludvigsson, D. and Trenter, C. (2021) 'The educational power of heritage sites'. History Education Research Journal, 18 (2), 264-79. https://doi.org/10.14324/ HERJ.18.2.08

Submission date: 7 October 2020

Acceptance date: 17 May 2021

Publication date: 19 October 2021

\section{Peer review}

This article has been peer-reviewed through the journal's standard double-blind peer review, where both the reviewers and authors are anonymised during review.

\section{Copyright}

(C) 2021 Stolare, Ludvigsson and Trenter. This is an open-access article distributed under the terms of the Creative Commons Attribution Licence (CC BY) 4.0 https://creativecommons.org/ licenses/by/4.0/, which permits unrestricted use, distribution and reproduction in any medium, provided the original authors and source are credited.

\section{Open access}

The History Education Research Journal is a peer-reviewed open-access journal. 


\title{
The educational power of heritage sites
}

\author{
Martin Stolare* - Karlstad University, Sweden \\ David Ludvigsson - Linköping University, Sweden \\ Cecilia Trenter - Malmö University, Sweden
}

\begin{abstract}
The aim of this article is to problematise the use of visits to heritage sites in history education in primary school. The empirical basis is a questionnaire and interviews with teachers in Sweden. Theoretically, the perspective is linked to the discussion of affective practices. The results show the connection that some, but not all, teachers recognise between different forms of historical knowledge. According to these teachers, visits to heritage sites activate the sensory experiences of the pupils, which has a positive impact on the pupils' learning. Two ideal approaches can be discerned when it comes to the use of visits to heritage sites in history education. Such visits form either a teacher-driven, integral part of the education, or the teacher assigns the display of the site to local guides. The two approaches can be related to the history subject that appears in education, although this is ultimately determined by the educational setting.
\end{abstract}

Keywords: primary school, teachers, history education, heritage sites, affective practices

\section{The role of heritage sites in history education in primary school}

Visits to heritage sites are a regular feature of history education, not least in primary school. This is the case in Sweden, as well as in many other countries (Dawson and De Pennington, 2000; Wilson and Hollis, 2007). In Sweden, the tradition of visiting heritage sites in history education goes back to at least the early twentieth century (Rantatalo, 2002). Why do teachers bring their classes to visit tombs, runestones, castles and folklore museums? What role do these visits play, and, according to teachers, what learning do the visits enable? This article addresses these questions.

Empirical research on the role of heritage sites in history education in primary school has mainly dealt with the perspective of the pupils, and the positive impact that visits seem to have on pupils' attitudes towards history as a school subject (Harris and Bilton, 2019). A number of studies have discussed teaching modules of which heritage sites have been a part, and how those site visits have influenced pupils' learning in history (Levstik et al., 2014; Marcus and Levine, 2011; McKernan, 2018; Rohlf, 2015).

Other studies have investigated teachers' use of museums, often from a generic point of view (for example, Kiesel, 2005), but also in connection to history education. On the basis of these studies, it can be said that teachers recognise economic aspects and other practical barriers as challenging, but also that teachers perceive visits as something positive, in that the pupils get to meet history 'first hand', which might influence their historical thinking (Marcus et al., 2012; Noel and Colopy, 2006). 
Teachers and pupils do not only visit formally institutionalised heritage sites such as museums. In previous research, the role of local history in primary education has also been addressed (Cooper, 1995; Hales, 2018). According to Cooper (1995) and others, the opportunities that come from linking history education to the local context can be related to teachers' perceptions of what is desirable history education in primary school. Primary teachers see great potential in local history, and express the idea of an expanded classroom, where visits to historic sites in the area are fully integrated and form a natural part of history education (Persson, 2017). Research has also been conducted on professional development projects to support teachers' use of more complex historical sources. One dimension of such work points to the value of strengthening teachers' experience of interacting with representatives of heritage sites and museums (Baron, 2013; Baron et al., 2019; Gómez-Hurtado et al., 2020; Jiménez Pérez et al., 2010). In this research, the notion of the expanded classroom emerges as an underlying idea.

\section{Sites, places and affective practices}

What unites the examples of the different kinds of site discussed above is that they are regarded as places defined by material and intangible traces of the past. A broad field of researchers have problematised heritage sites from a common overall standpoint; namely that heritage sites are open to interpretation, and that, as such, they are continuously being made. Two focal points steer the research about the dialectic between visitors and heritage sites. First, due to the differentiality in interpretations and meaning making, historic sites are contentious. Sites appear as processes, open to interpretation and reinterpretation, and the importance of heritage sites cannot be easily separated from the individual or group that experiences the place. Second, historic sites can be interpreted in different ways, but not in any way; the visitor is steered by expectations and common values, as well as by the fashion in which the heritage site is displayed and presented. Visual studies, tourist studies and media studies have paved the way for wider reception studies of heritage sites, including the reception of institutionalised heritage sites such as museums and theme parks, as well as landscapes in terms of memoryscapes or historyscapes (for example, Dicks, 2004; Erll, 2011; Erll and Rigney, 2009; ToliaKelly et al., 2017). Barbara Kirshenblatt-Gimblett (1998) has suggested the term 'agency of display' to capture the processes of arranging and displaying sites. In the present study, teachers are defined as visitors with an agency of display - due to their pedagogical positions - who define and steer the excursions and their uses of heritage sites in education. Aligning with De Nardi (2020: 20), who studies visualisation of places by drawing on affective theories by Wetherell, Stoller and Bender, we argue that places are never abstract because 'social knowledge [is] always situated somewhere'. In other words, heritage sites are valued in terms of being places loaded with educational power by the teachers.

An examination of how teachers perceive heritage sites and their function in history education relates to discussion of how pupils learn history. In this sense, it is possible to link the role of heritage sites to the aspects of different forms of historical knowledge.

Jörn Rüsen's disciplinary matrix, available in several different versions, could be seen as a model for the process of historical learning (Körber, 2015). In the matrix, the experience of the past appears as the substance of history education. It is this experience that is interpreted, becoming the foundation for a functional narrative that helps the 
pupils to orient themselves in the present and the future (Rüsen, 2017). The past can be experienced in different ways. In the classroom, pupils learn historical narratives by reading, watching movies or listening to the teacher. But pupils might also be given the opportunity to experience the past more directly: as knowledge by acquaintance (Winch, 2013). When touching historical artefacts, such as axes from the Stone Age and letters from the nineteenth century, or visiting heritage sites and experiencing the ruins of a medieval castle, historical learning is no longer an exclusively cognitive practice (Curtis, 2015; McKernan, 2018; Trofanenko, 2014; Witcomb, 2013). The concept of knowledge by acquaintance points to a learning process in which a broad spectrum of senses might be put in play. Here the feelings and emotions, products from sensory experiences, are integrated into the process of historical meaning making. In this regard, knowledge by acquaintance opens up the idea of material perspectives and an embodied understanding of history (see Curtis, 2015; Witcomb, 2013; Zachrich et al., 2020). In this article, the concept of affective practices is used to address these aspects of historical learning and meaning making.

In recent decades, affections and the explanatory power of emotions have been highlighted in social science research. In this regard, researchers have spoken of a turn to affect (Wetherell, 2012; Trofanenko, 2014). The concept of affective practices has been suggested by Margaret Wetherell; it places an emphasis on the sensual, and on the affections and emotions that are stimulated by it. The concept points towards a non-dualistic position, where the sensual and bodily material dimensions are intertwined with the discursive cognitive aspects of understanding (Smith et al., 2018; Wetherell, 2012). Thus, one may engage in affective practices, but that engagement is not always conscious; it is a process of embodied meaning making that might be called pre-reflexive. A link could be made to Hans-Ulrich Gumbrecht (2004) and his discussion of the concept of presence, which points to the need for transcending a reflexive approach (Bjerre, 2019). Whether the teachers taking part in this study express the notions of affective practices and a pre-reflexive approach is something that has to be addressed empirically.

\section{Aim and research questions}

The aim of this article, based on teachers' accounts of their teaching, is to problematise the use of visits to heritage sites in history education in primary school. Two research questions were formulated to guide the empirical work and analysis:

1) What heritage sites do teachers visit, and what educational (didactical) motives do teachers express regarding visits to heritage sites?

2) How do teachers perceive the role of sites in a process of historical learning? Are heritage sites used similarly to other teaching resources, or do the sites represent a separate path to historical knowledge?

The research questions should be understood as relating to history education in Swedish primary schools. In lower primary school, the pupils are between 7 and 9 years old, and the focus is traditionally on prehistoric times and the history of the local area. The perspective is somewhat different in upper primary school (for children between 10 and 12 years old), where the emphasis is on Swedish history, focusing on the origins and development of Swedish society from the Viking Age to the societal transformations of the eighteenth and nineteenth centuries (Eliasson and Nordgren, 2016; Stolare, 2014). 


\section{Methodology}

The study combines data from an online questionnaire, 2 group interviews and 11 qualitative interviews with teachers (Drew et al., 2008). The questionnaire included 17 questions, organised in two thematic blocks. The first block covered background factors, including questions about the teachers' gender and teaching experience. The second block looked into aspects of how excursions to historic sites are used in teaching. To capture this aspect, questions were asked about which heritage sites were visited and why. Teachers were also asked to give examples of excursions to heritage sites that they thought had been particularly successful, and which sites they would like to use for visits if they had the means. The questionnaire combined open-ended questions and multiple-choice questions with predefined answers. For multiple-choice questions, an optional space was provided to elaborate on the answer. Email was used to contact 635 principals of local schools, inviting them to distribute the link to the questionnaire to teachers in their schools. About 260 respondents completed the questionnaire, but only some of the principals confirmed that they had distributed the link to their staff. Thus, it is uncertain how many teachers were reached, and the exact number of non-responses cannot be estimated.

Since the proportion of invited teachers who answered the questionnaire cannot be established, the questionnaire has not been used for quantitative analyses or generalisations (Edmonds and Kennedy, 2017). Making generalisations is not the purpose of this qualitative study; the focus is on the teachers' expressed motives and reasoning about visits to heritage sites. The open-ended questions were used to note potential patterns of visits to heritage sites. A thematic analysis was made of responses to the open-ended questions (Guest et al., 2012). As the result of a first close reading, provisional categories were created that related to the study's research questions. After this first phase, during which the research group jointly read, compared and discussed the categories, two more close readings were carried out to determine reasonable boundaries for the different categories.

Interviews were conducted with 10 teachers (2017-19). Interviewees were chosen (using criterion sampling) on the basis that they had planned to bring their class to a heritage site - and that visit was accompanied by a researcher (Ludvigsson). The researcher then interviewed the teacher at his or her school, shortly after the field trip. Interviews dealt both with what had happened during the specific excursion and with the teacher's general ideas about using visits to heritage sites in education. Each interview took about thirty or forty minutes. In this article, the teachers have been given pseudonyms referring to the sites they visited with their pupils: 'Alvastra', 'Bjäsäter', 'Cathedral', 'Löfstad palace', 'Motala industrial area', 'Old Linköping', 'Vist' and 'Vadstena castle'. Pseudonyms have also been assigned based on the theme behind the visit: 'The Witch Forest' and 'Medieval times in the cathedral'. In addition to the individual interviews, two group interviews were held (in spring 2019) with 11 teachers at two public schools, located in different regions. One school (Group Interview 1) was located in Östergötland, a region in eastern Sweden with both urban and rural areas. This is a central region, as defined in terms of Swedish political history, with a broad selection of historic sites from the Middle Ages to the present day. The teachers at the other school (Group Interview 2) worked in Värmland, a region in western Sweden bordering Norway, with relatively few traces of older history. Värmland can be characterised as predominantly rural. The purpose of the group interviews was to obtain a more in-depth picture of how teachers perceive visits to heritage sites in 
the context of their teaching assignment. Each interview took roughly one hour. Two researchers (Stolare, Ludvigsson) held one group interview each.

The interviews with the teachers, both individually and in groups, provided opportunities to reach a nuanced idea of the teachers' perceptions, which has been achieved through thematic analysis (Guest et al., 2012). The unit of analysis here is the teachers' statements about the role played by visits to heritage sites in their teaching. The analysis focuses on linguistic aspects, such as which concepts and terms are used by the teachers. In the analysis of the group interviews, the linguistic interaction between the participant teachers was an essential dimension; a common pattern was sought through a thematic analysis. However, the two group interviews were organised in places that differ from each other in relevant aspects, making it possible to discuss the impact of the broad school context on teachers' perceptions.

\section{Findings}

\section{What heritage sites are visited?}

Table 1 captures the diversity of heritage sites that the teachers in the survey reported that they visited with their classes. The variety reflects the varied heritage landscape in the part of Sweden where the survey was conducted, but also clearly connects with which aspects of history are emphasised in the curriculum. For example, the large number of ancient monuments, rock carvings, runestones, traces of the ice age, trapping pits and stone ships reflect the fact that pre-medieval history is dealt with in lower primary school. It can be noted that teachers have included museums in their definition of heritage site. Indeed, museums are listed as the single most common heritage site visited. However, although museums often display historical artefacts, they are not usually heritage sites in themselves.

\begin{tabular}{llll}
\hline \multicolumn{2}{l}{ Table 1: Heritage sites visited according to the teachers } & \\
\hline Heritage site & $\begin{array}{l}\text { Number } \\
\text { of teachers }\end{array}$ & Heritage site & $\begin{array}{l}\text { Number } \\
\text { of teachers }\end{array}$ \\
\hline Museum & 102 & Unnamed sites near the school & 12 \\
Folk museum (Hembygdsgård) & 71 & Ancient village (Forntidsby) & 11 \\
Ancient monument & 68 & Canal, port, lighthouse & 11 \\
Church, church ruin & 61 & Famous historical places & 11 \\
Castle, castle ruin & 42 & Cultural historical landscape & 10 \\
Palace, mansion & 42 & Small farm building (Torp) & 9 \\
Old buildings & 32 & Old road, railway or route & 8 \\
Traces of the ice age & 28 & Excavations & 6 \\
Old industry & 26 & Stone ship (Skeppssättning) & 4 \\
Runic stone & 25 & Trapping pit & 3 \\
Historical town & 24 & Gallows hill & 2 \\
Historical walk & 19 & Old prison & 2 \\
Rock carving & 18 & Amusement park (Folkpark) & 1 \\
Monastery (ruins) & 16 & Battlefield & 1 \\
Cemetery & 13 & Shelter & 1 \\
Statue, memorial & 13 & Traces of emigration & 1 \\
\hline & & & \\
\hline
\end{tabular}

Note: The respondents were allowed to specify more than one heritage site. 


\section{Using ready-made school programmes or visits to heritage sites as an integral part of teaching}

A large majority of the teachers in the survey stated that they contact guides, museum educators or volunteers from a local heritage association in advance of their visit. When using ready-made school programmes, the teachers declare that they tend to hand over the educational questions to the people guiding the class (Teacher: Old Linköping, Bjäsäter, Vadstena Castle):

You hand over, what should I say, the teaching knowledge part to someone else. So [my role] becomes very much to keep things together ... Take care of the pupils you know have difficulties in these situations. Hugging them. Sending them on a run, in order to make it work. (Teacher: 'Alvastra', 09.17)

Thus, teachers take on a different role, providing implicit and social support to the pupils (Teacher: Cathedral). It is also their role to link what the guide is saying to what they have been doing in class, which is accomplished by putting questions to the guide (Teacher: Bjäsäter).

The prevalence of ready-made school programmes varies between different regions, which becomes clear when the two group interviews are compared. Group Interview 1 was conducted in a region where the national narrative was explicitly present. Some of the sites and places in the region were even referred to in textbooks. By contrast, Group Interview 2 took place in a region that, both today and historically, can be described as largely peripheral, and that is invisible in the national narrative related by textbooks.

The importance of school programmes was emphasised in Group Interview 1. The teachers want material where traditional historical factual information is intertwined with tasks and stories that appeal to the pupils' imaginations and generate enthusiasm for the upcoming visit:

The fact that there are ready-made concepts, I think increases the chance that the teacher takes it [the class] there because it is prepared a little. It is not that we are lazy and unable to plan, but time is so scarce and tight nowadays. (Group Interview 1, 35.24)

This issue was not at all relevant in Group Interview 2, which, as mentioned, was carried out in a region that lacked the possibility of visiting more institutionalised heritage sites.

A minority of the teachers in the survey claimed that they handle the visits entirely on their own. An illustrative example of this is the teacher who describes how he takes his class on a bicycle ride with a tent sleepover. During this bicycle tour, the class visits various heritage sites in the home area:

Bike tour with ancient monuments in the centre. We cycled around $10 \mathrm{~km}$ in the surrounding area for a whole day. We stopped at many ancient sites and talked, showed and discussed the history and people behind. After the bike ride, we slept over in tents to the next school day. A great day. (Teacher survey)

Perhaps the bicycle tour represents a slightly different way of using visits to heritage sites as part of history education, visiting places that are not institutionalised with guides or school programmes. Table 1 shows that many of the visits to historic sites focus on historical remains such as tombs, runestones and historic buildings, which can be seen as historical monuments in the local area. These are places that may be within easy reach for the teacher, to which they can walk or cycle, and that can be 
visited more informally. This is especially true for participants in Group Interview 2. One of the teachers in the group describes how she used to take her class on a historical excursion by foot, around the town, carrying a photograph album with her. According to the teacher, the basic condition for carrying out such an excursion was her own knowledge. She could do it because this was her home town, of which she had deep historical knowledge. However, this changed when she moved and started working as a teacher in a nearby village that she did not know so well (Group Interview 2, 4.41).

\section{Teachers' didactical choices and motives for visiting heritage sites}

In a free-text response in the questionnaire, respondents were asked to justify why they visited the various places they had listed. Of the 260 teachers who answered the questionnaire, 194 answered this question. A number of motives for the visits were crystallised in the analysis. These were inductively formed as categories, which are presented in Table 2.

The largest category of response among teachers who answered this question explains the motives for their visits by linking them to what they have been teaching. For example, when teaching about ancient times, they look for remains in the local area. One teacher wrote: 'Have worked with the Iron Age and Middle Ages and these visits are a great fit.' This integration or interaction with the teaching is also evident in the interviews with teachers (Teacher: Old Linköping, Bjäsäter, Cathedral, Vist, Motala industrial area). However, interviews made it explicit - especially in the case of upper primary school classes - that visits could not always be linked to what was being taught at that point in school (Teacher Alvastra, Löfstad Castle). Such visits would have a different character, and where pupils had not been very prepared for the visits, follow-up work would also be different. This indicates that the reasons for the visits to heritage sites are not only educational. Although few teachers in the survey gave social reasons for the visits (building relationships with or between pupils), such a motive was highlighted by several teachers in the individual interviews (Teacher: Vadstena Castle, Löfstad Castle, Medieval times in the cathedral, Old Linköping).

Table 2: Teachers' motives for visiting heritage sites

\begin{tabular}{lc}
\hline Motive & $\begin{array}{c}\text { Number of } \\
\text { teachers }\end{array}$ \\
\hline The teaching - the sites align with what is taught & 83 \\
Historical learning - enables learning & 48 \\
Bildung/formation - learn about the local community & 40 \\
Proximity, closeness - economic and geographical: & 34 \\
in-reach arguments & 31 \\
Tradition - established contacts, 'We always visit these sites' & 13 \\
The steering documents - in accordance with the syllabus & 9 \\
Variation - interesting, 'doing something else' & 3 \\
Social - getting to know each other & 1 \\
Combination - learning other things too & \\
(for example, traffic safety, citizenship education) & 262 \\
Total & \\
\hline
\end{tabular}

Note: Respondents could present several motives. 
An apparent motive behind the visits is that the pupils should learn more about their local community. Here, the visits constitute part of a formation process (Bildung) where dimensions of constructing a local identity are addressed: 'I want to awake the pupils' interest for their home town. Give the pupils knowledge of the roots and history of the place where they live', as one teacher in the survey states. These statements - to recognise visits to heritage sites as an aspect of Bildung and the formation of local identity - are entirely in line with what has been said in previous research regarding the tradition of history and social studies subjects in Grades 1 to 3 in Sweden. Since at least the beginning of the twentieth century, visits to local heritage sites have been part of the Swedish syllabus, and they still are. By comparison, history education for Grades 4 to 6 focuses more on a national narrative. This is also evident in the current syllabus, from which local perspectives are largely absent (Stolare, 2014). In light of this situation, visits to heritage sites in Grades 4 to 6 might be seen rather as part of a strategy to illustrate the national historical narrative. One clear example of this in the empirical material is the class that visited the place where witch trials were held in the 1600s. Witch trials are a part of the historical canon, and feature explicitly as such in the history syllabus of upper primary school (Skolverket, 2017).

One common motive for a visit to a heritage site is that the teacher receives an offer from a cultural heritage institution (such as a museum), whose education team are running various school programmes. It could also be an invitation from a local heritage association offering the class a guided tour of the local folklore museum. Sometimes these visits take place within the framework of specific projects, but it is apparent from the teachers' responses that often they are recurring elements that have become part of a local tradition:

We always make a field trip with Grade 5 in the autumn to Stockholm. We read about the Middle Ages in Grade 4, and the sixteenth century in Grade 5. Then we visit the Natural History Museum, there is also history. Ancient history, however, we study in lower primary, but we can only afford to go on one trip to Stockholm during Years 1-6. In Grade 3, we go on a Värmland [county] tour, where we visit both Karlstad, Värmland Museum and Mårbacka [home of a famous writer], the town museum when we visit the town. We are a rural school. (Teacher survey)

At the school where one of the interviewed teachers worked, there is an annual planning cycle for the various extramural activities (Teacher: Alvastra). The type of motive referred to here as tradition points to the fact that it is not always the individual teacher who initiates visits to heritage sites.

The question of reach is a fundamental factor: 34 teachers cited this as a reason for having visited the places they indicated in the survey (see Table 2). According to the teachers, economic reasons explain why they visit some places but not others. The teachers link economic reach to geographical reach. Thus, an important explanation and reason for the choice of some of the sites listed in Table 1 is that they are easy to get to. When there are sites to which the class can walk, cycle or take public transport, rather than having to charter an expensive bus, the former are chosen. Some sites are in the immediate vicinity of the school, and, as one teacher put it in the survey: 'We can walk there. We have graves from ancient times in the area that we would like to visit, but then we have to hire a bus, and we do not have the money for that' (see also Teacher: Cathedral, Alvastra, Old Linköping, Vadstena Castle). 


\section{Visits to heritage sites as a catalyst for historical learning}

In the introduction, drawing on the work of Rüsen (2017), we discussed the importance of offering pupils an opportunity to meet and experience history. The standpoint was that experience is to be understood as a necessary step in the process of historical learning. Mostly, pupils experience history by listening to the stories and accounts told by the teacher, by reading textbooks, by watching films and looking at pictures, or sometimes by working with historical sources. In many of these learning situations, the encounters with history are indirect, with a strong focus on deepening the pupils' abilities to engage in historical thinking and reflection. Only rarely might pupils meet history in the sense of real traces of the past (Bjerre, 2019). During visits to heritage sites, pupils are given a chance to experience such traces first hand - an approach that could open up alternative and complementary paths to historical learning. Therefore, it is of particular interest to examine the teachers' understanding of the role and function of visits in a process of historical learning. The starting point for discussion of this issue is the survey.

As shown in Table 2, 48 teacher respondents to the survey emphasised that visits to heritage sites have a positive impact on pupils' learning of history. For these teachers, learning appears to be a primary motive for making these visits. One approach is that visits to heritage sites are a way to verify what has been said in the classroom; when on site, pupils have the opportunity to see things with their own eyes (Teacher: Old Linköping, Löfstad Castle, Witch Forest, Motala industrial area, Vist). For the teachers, visits to heritage sites can be a tool in the transformation process, allowing them to make concrete the otherwise often abstract history lessons:

The purpose, I think, is to somehow make what we read here at school a little more vivid, a little more real, which it actually is. It has happened. But for some [pupils] it can be too abstract, you sit and read books and watch movies. ... if you have the opportunity at your school, you should ... go to some heritage site or museum, so they understand that this is something that not only I tell in our little classroom, that we read about in the book. It is a little bigger than what we do here. (Teacher: Vadstena, 00.19)

The idea that visits make teaching less abstract, and that visits add an extra dimension, is expressed by teachers in the survey. Commenting on why they visit heritage sites, one teacher explains that the puporse is: 'To visualise what we just worked with, to anchor what we work with, put flesh on the bones of the textbook.' Another writes: 'Instead of just looking in a book/screen it gives a different feeling.' In the teachers' speech about what can motivate visits to heritage places are words or expressions such as: 'to see with their own eyes', 'touch' and 'to experience'. A teacher who brought her Grade 3 class to a day organised by the local heritage association stated:

I wish we could have experienced that part [the forge] a little more. But otherwise I felt it was very much, it was for real and it is cool when it is for real. It is different than seeing it on film, or someone telling you about it ... It becomes a different encounter and a completely different experience. (Teacher: Bjäsäter, 08.35)

This teacher's view links to yet another perspective raised by the teachers in the survey. A positive effect of visits to heritage sites may be the feeling of authenticity - what the pupils experience during the visits is actually in some way true. According to the teachers, the pupils sense that they meet the past unfiltered. The teachers in Group 
Interview 2 suggest the importance of authenticity as a resource in a teaching situation. To them, there is also a qualitative difference between a museum and the real traces of the past that can be encountered elsewhere in the local community (Group Interview 2, 3.44).

Both in the survey and in the interviews, teachers express that there is a certain quality to the encounter with a heritage site. The visits provide other opportunities for learning than can be established in a classroom setting. This raises questions about space and materiality, but also about the notion of presence. In the aforementioned teachers' argument, the heritage site appears as teaching material; it is used to confirm things that have been discussed in the teaching or to make the historical content more concrete. Here, perspectives on distance, analysis and reflection come into the foreground. However, by raising questions about different historical forms of knowledge in connection with the concept of affective practices, a sensual, bodily and material approach to the past becomes more prominent. Therefore an explicit cognitive position, where pupils are asked to reflect, could be a problem, as it might prevent a direct experience of the past, and an experience characterised by presence (Gumbrecht, 2004), or, as one teacher wrote in the survey, addressing the issue of using different senses in the process of historical learning, 'for learning to take place in different ways and with different senses'. The teacher who took his class to the town cathedral emphasised the importance of sensual, bodily experiences as a path towards historical learning: 'Seeing it physically [life in the Middle Ages], to experience it physically provides a different understanding than reading about it' (Teacher: Medieval times in the cathedral', 08.52). Emphasis on another kind of understanding was also expressed by other teachers in the interviews (Teacher: Witch Forest, Old Linköping).

The added value that can come from visits to heritage sites became a theme in the group interviews, especially for the teachers in Group Interview 1. The conversation between the teachers reveals their understanding that pupils need to gain experiences of history. It may not be enough to describe what happened. Rather, pupils must get to know, see, experience and smell. Many senses need to be activated in order to learn history (Group Interview 1, 09.07). The teachers also point to a particular capacity that traces from the past might have, since they can have the power to function as time machines, connecting you with people of previous generations.

The teachers in Group Interview 1 emphasise the importance of pupils being in the environment, playing and discovering it (Group Interview 1, 31.01). Pupils' original thinking also became a theme in Group Interview 2. As a teacher, they say, you do not need to be afraid of letting pupils free, but should rather allow them to discover the place and create their own interpretations:

... if you have a rock carving, sod the history about what it is, let them think around it. What is this? Make a drama or let them play archaeologists and scientists themselves and come up with their own ... Then I think it would be much more fun. A little storytelling. (Group Interview 2, 40.00)

\section{The relationship between visits to heritage sites and teaching in the classroom}

In the group interviews, another aspect was highlighted regarding the interaction between visits to heritage sites and classroom teaching. The key concepts that emerge from the teachers' accounts are experience and the formation of a common frame of 
reference. Interestingly, the perspectives are diametrically different in the two group interviews.

The teachers in Group Interview 1 relate to what has been said above about the unique opportunities that may characterise visits to heritage sites concerning pupils' more direct and explicit encounters with the past, and the effect that these visits can have on their learning in history:

I think it is important to create memories. In the last class, we were in the mill area, we cycled there and then we can always relate to it. Do you remember when we were? Yes, that stove there! Yes, they [the pupils] got something to hang everything on. And I think that excursions can help, to become something you hang things on, the knowledge on. And those pegs have become fewer in today's children. Pupils used to have more of those ... but now they arrive without any [pegs], and then I think in some way that we must create them. (Group Interview 1, 10.48)

Having shared historical experiences is referred to as a necessity. These experiences become reference points that the teachers say they can use (Group Interview 1, $28.31,41.05)$. In discussion, the teachers express the notion that there is a gap in historical experience and reference between them and the pupils. In their view, this gap has become wider in recent years. The pupils' frames of historical reference and experiences have changed. According to the teachers in Group Interview 1, visits to historic sites are needed in order to create experiences or memories that can function as cognitive historical pegs for pupils.

The teachers in Group Interview 2 addressed the role of experience in historical learning more indirectly; in this case, the relationship was the opposite. The teachers in Group Interview 1 connected the teaching content to a 'reality' outside the classroom that the class had jointly visited, while the teachers in Group Interview 2 highlighted their strategy to link their teaching to experiences outside the classroom walls that the pupils and teachers shared, without actually having visited the places together:

Teacher: Sometimes you don't have to go there with a whole class either. We have sometimes ... taken it into the classroom instead. The history that you've been talking about. You know that war! Everyone knows all these places ... I refer to something they know. For example, those in the class who are farmers - how did the farmers have it with houses and allotments then? ... and compare it with things they already know. ... So, we talk a lot about the local area, but in the classroom.

Interviewer: You don't necessarily have to be there.

Teacher: No, we don't have to go there. Most pupils have been to each other's homes and know what places we're talking about. (Group Interview $2,22.27)$

This teacher expresses the notion of a shared historical frame of reference, and that this can serve as a resource in teaching. An explanation for the two different approaches can undoubtedly be found in the contexts in which the teachers are located. The different approaches not only affect the role that visits to heritage sites play in teaching, and how they are used, but also what specific history is being represented. In Group Interview 2 , heritage sites can be a way to show that the pupils' home town actually has a history that can be linked to the national narrative they encounter in the textbooks. Teachers see it as their responsibility to make that point. For this reason, they have even visited their regional archive to get more information on the local sources available: 
Teacher 1: We have many centuries of war history ...

Teacher 2: Yes, there is [much] ...

Teacher 1: ... to work with. Although that's what I think is fun, because it's a bit like what happened in Lützen [a canonised battle in 1632] also happened here. (Group Interview 2, 15.15)

It is apparent that teachers in Group Intervew 2 perceive their home region to be a kind of historical periphery, being invisible in textbooks and the national narrative. At the same time, the teachers express pride, or at least a belief that it is crucial for the pupils to study the history of their local community:

Teacher 2: I think it's important that we use the history we have here ... Now, I have the Grade 8 pupils - history and geography together - they go out and study the community to see what there is here today and what there was in the past. (Group Interview 2,16.16)

The conditions are different in Group Interview 1. The visits discussed can clearly be linked to the national narrative in the textbooks. Here, the perspective becomes rather that of a historical centre, since this region has been a part of Sweden since the Middle Ages and, several centuries thereafter, can be referred to as a central part of the kingdom. Perhaps these different positions - located in the historical centre or historical periphery - partly explain why the function and use of visits to heritage sites appear so different between the two groups.

\section{Conclusions}

According to this study, Swedish primary school teachers visit institutionalised heritage sites as part of their teaching, be they museums, historic buildings or other heritage sites. That such sites dominate can be related to the fact that many of the teachers in the survey state that they do not do the guiding themselves. In terms of agency to display (Kirschenbladdt-Gimlett, 1998), the teachers hand the interpretive prerogative to the guide, stepping into the background themselves. Only a minority of teachers declare that they choose not to contact local representatives, and consequently to take full organisational and substantive responsibility for the visit to heritage sites. The empirical basis for this study makes it difficult to unequivocally determine why teachers choose to adopt this more passive role. One possible explanation could be that the teachers feel insecure, and lack the tools to make the visits an integral part of their teaching. Research by Baron (2013), Baron et al. (2019) and Jiménez Pérez et al. (2010) on professional development in relation to the use of historic buildings and heritage in teaching provides some support for such a conclusion.

When the teachers in the study are asked to explain the reasons for their visits, they claim that the places chosen align well with what they have been teaching. Another important motive is that the visits offer opportunities for the pupils to study the history of their home area, which may be interpreted as an ambition to stimulate formation (Bildung). Third, the teachers express the notion that visits to heritage sites can contribute to historical learning in a manner that cannot be achieved in the classroom, making history more concrete. The teachers point out that it is not enough for the pupils to know the narrative by reading textbooks or watching films, but in order to really understand, the pupils must encounter actual traces of the past. This motive was especially prominent in the individual interviews and the two group interviews. These results align well with those from previous research (Cooper, 1995; 
Hales, 2018; Levstik et al., 2014; Marcus et al., 2012). However, some of the teachers suggested that visits to heritage sites offer additional value, such as giving pupils the opportunity to use their senses and to discover the site through playing, that is, to learn in a different way than is possible in the context of ordinary teaching. To these teachers, pupils' material, physical and sensory experiences, and the feelings and emotions stimulated by their encounter with the site, appear as essential resources in the process of historical learning. For the teachers, there is no contradiction between cognitive and affective dimensions of history education; instead, these dimensions strengthen each other. In their teaching, the teachers taking part in this study use and enrich the affective practices associated with the site (Smith et al., 2018; Wetherwell, 2012). These findings indicate that it could be fruitful to use the concept of affective practices to frame teachers' decisions to visit heritage sites with their classes.

By relating affective practices to the educational ideas of the teachers, this study has, therefore, contributed to the field of research (McKernan, 2018; Trofanenko, 2014; Witcomb, 2013). Based on their proven experience, the teachers in the survey and in the interviews signal that there are several complementary paths to historical knowledge; cognitive approaches must be combined with affective approaches. This would suggest the value of further research, to systematically, critically and empirically examine teachers' experiences, using the idea of affective practices as a possible approach. However, as Zachrich et al. (2020) have outlined, there may be analytical reasons to distinguish the physical from the affective. The material aspect of complex sources (which heritage sites present) clearly reprsents a distinctive dimension in teaching and learning in history.

It is tentatively possible to recognise two ideal approaches regarding agency in displaying heritage places in primary school (Kirschenbladdt-Gimlett, 1998). The two group interviews illustrate, in a simplified way, these two approaches. In Group Interview 1, the teachers declare the need to visit certain heritage sites in order to encourage pupils to establish a necessary historical frame of reference. Central to the conversation in Group Interview 1 seems to be a perceived subject content tradition, and a focus on the national narrative presented in the textbook. The visits then become a way to encounter the places that pupils have studied in class. This approach is possible if the school is located in what could be characterised as a historical centre, visible in the national narrative. By extension, this might have an impact on the history subject represented. The question of path dependence is relevant: a certain (taken-for-granted) narrative may follow from a site, and with it a particular historical representation. The teacher can choose to challenge the taken-forgranted interpretation of the site. However, that requires conscious action on the part of the teacher, developing a reinterpretation of the site. In the end, what history the site may represent is decided by the teacher in interplay with pupils and the general educational setting.

The perspective is very different in Group Interview 2. The notion of being in a historical periphery permeates the conversation. The teachers in this group say that they would like to have ready-made school programmes, but that there are none available to them. Their local conditions are invisible in textbooks, and in the national narrative expressed in primary school. It is not possible to visit the places mentioned in the national narrative, as they are too far away. While teachers could try to find sites in the local area that may represent this narrative, this group of teachers point instead to the importance of visiting sites that have significance and relevance as a part of a local historical narrative. These visits are presented as teacher-initiated and teacher-led, and are well integrated in history education. Thus, the local history that it is possible to 
discover outside the school classroom becomes the starting point for them: a kind of history from below. In this way, it is rooted in a local history culture and linked to the notion of a collective historical consciousness. The teachers in Group Interview 2 express a view that history has an emancipating potential, and here the visits to heritage sites have a unique function, namely to forge a connection with the place where the pupils (and teachers) live their lives. This is not to claim that a local narrative, by definition, is to be characterised as more open to different interpretations than a national one, but the stronger focus on the local does at least mean that more than one perspective on the past is available. Grever (2007) has identified the lack of different perspectives as one of the significant problems with a history education defined by a distinct canon. Visits to heritage sites with relevance to local history appear to be one way to open up such a canon.

To conclude, the educational setting has a considerable impact on which sites are visited and how the visits are executed. Reach (economic and geographical) and school tradition are crucial factors here. Thus, the school's location shapes the opportunities for teachers' actions. Visits also have to be understood in relation to the educational ideas that underpin them. That is to say, it is not the site in itself that fully determines what history the pupils get to experience. Heritage sites remain dynamic and open for interpretations.

\section{Funding}

The project on which this article is based, School Children Relate to Historical Sites, is funded by Riksantikvarieämbetet (Swedish National Heritage Board) (3.2.2-5128-2016). The authors are responsible for stated opinions and factual information.

\section{Research ethics statement}

The authors declare that research ethics approval for this article was provided by the Regional Ethics Board, Linköping University.

\section{Consent for publication statement}

The authors declare that research participants' informed consent to publication of findings - including photos, videos and any personal or identifiable information - was secured prior to publication.

\section{Conflicts of interest statement}

The authors declare no conflict of interest with this work

\section{Notes on the contributors}

Martin Stolare is a professor of history and history education at Karlstad University, Sweden. He has a wide range of research interests, with a particular focus on history education in primary and especially upper primary school. He explores the interplay between history as a scientific discipline and history as a school subject, and he is currently developing models for teaching on social issues in the social sciences classes with students in Grades 4 to 6. 
David Ludvigsson is a senior lecturer in history at Linköping University, Sweden. He deals with several fields of historical research. He has analysed the genre of historical documentary film, political uses of the Holocaust, the teaching and learning of history, and how humour interacts with history in historical comedy film. He has also investigated the role(s) of guides in the cultural heritage sector.

Cecilia Trenter is a senior lecturer in history at Malmö University, Sweden. She works within the research field of memory studies and public history, including historiography, and epistemological and ethical approaches to knowledge production. She is researching heritage adaptations and remediation in fiction, for instance epic films and computer games, and she is studying heritage sites with educational approaches. She also writes fantasy and teaches classes in creative writing.

\section{References}

Baron, C. (2013) 'Using inquiry-based instruction to encourage teachers' historical thinking at historic sites'. Teaching and Teacher Education, 35, 157-69. https://doi.org/10.1016/j. tate.2013.06.008.

Baron, C., Sklarwitz, S., Bang, H. and Shatara, H. (2019) 'Understanding what teachers gain from professional development at historic sites'. Theory \& Research in Social Education, 47 (1), 76-107. https://doi.org/10.1080/00933104.2018.1489927.

Bjerre, L.I. (2019) 'Fortidens rolle i historieundervisningen: En analyse af det historisk fremmede i grundskolens historiefag'. PhD thesis, University of Southern Denmark.

Cooper, H. (1995) History in the Early Years. London: Routledge.

Curtis, E. (2015) 'The place of time in children's being'. In A. Hackett, L. Proctor and J. Seymour (eds), Children's Spatialities: Embodiment, emotion and agency (Studies in Childhood and Youth). New York: Palgrave, 39-53. https://doi.org/10.1057/9781137464989_3.

Dawson, I. and De Pennington, J. (2000) 'Fieldwork in history teaching and learning'. In A. Booth and P. Hyland (eds), The Practice of University History Teaching. Manchester: Manchester University Press, 166-78.

De Nardi, S. (2020) Visualising Place, Memory and the Imagined. London: Routledge.

Dicks, B. (2004) Culture on Display: The production of contemporary visitability. Maidenhead: Open University Press.

Drew, C.J., Hardman, M.L. and Hosp, J.L. (2008) 'Introduction to qualitative research and mixed-method designs'. In C.J. Drew, M.L. Hardman and J.L. Hosp (eds), Designing and Conducting Research in Education. Thousand Oaks, CA: Sage, 183-208. https://dx.doi.org/10.4135/9781483385648.n8.

Edmonds, W. and Kennedy, T. (2017) 'A primer of the scientific method and relevant components'. In W. Edmonds and T. Kennedy (eds), An Applied Guide to Research Designs. Thousand Oaks, CA: Sage, 1-28. https://dx.doi.org/10.4135/9781071802779.n1.

Eliasson, P. and Nordgren, K. (2016) 'Vilka är förutsättningarna i svensk grundskola för en interkulturell historieundervisning?'. Nordidactica: Journal of humanities and social science education, 2, 47-68.

Erll, A. (2011) Memory in Culture. Basingstoke: Palgrave Macmillan.

Erll, A. and Rigney, A. (eds) (2009) Mediation, Remediation, and the Dynamics of Cultural Memory. Berlin: Walter de Gruyter.

Gómez-Hurtado, I., Cuenca-López, J.M. and Borghi, B. (2020) 'Good educational practices for the development of inclusive heritage education at school through the museum: A multi-case study in Bologna'. Sustainability, 12 (20), 8736. https://doi.org/10.3390/su12208736.

Grever, M. (2007) 'Plurality, narrative and the historical canon'. In M. Grever and S. Stuurman (eds), Beyond the Canon: History for the twenty-first century. Basingstoke: Palgrave Macmillan, 31-47.

Guest, G., MacQueen, K.M. and Namey, E.E. (2012) 'Themes and codes'. In G. Guest, K.M. MacQueen and E.E. Namey (eds), Applied Thematic Analysis. Thousand Oaks, CA: Sage, 49-78. https://dx.doi.org/10.4135/9781483384436.n3.

Gumbrecht, H.U. (2004) Production of Presence: What meaning cannot convey. Stanford, CA: Stanford University Press.

Hales, A. (2018) 'The local in history: Personal and community history and its impact on identity'. Education 3-13, 46 (6), 671-84. https://dx.doi.org/10.1080/03004279.2018.1483802. 
Harris, R. and Bilton, H. (2019) 'Learning about the past: Exploring the opportunities and challenges of using an outdoor learning approach'. Cambridge Journal of Education, 49 (1), 69-91. https://doi.org/10.1080/0305764X.2018.1442416.

Jiménez Pérez, R., Cuenca López, J.M. and Ferreras Listán, M. (2010) 'Heritage education: Exploring the conceptions of teachers and administrators from the perspective of experimental and social science teaching'. Teaching and Teacher Education, 26 (6), 1319-31. https://doi.org/10.1016/j. tate.2010.01.005.

Kiesel, J. (2005) 'Understanding elementary teachers' motivations for science fieldtrips'. Science Education, 89 (6), 936-55. https://doi.org/10.1002/sce.20085.

Kirshenblatt-Gimblett, B. (1998) Destination Culture: Tourism, museums, and heritage. Berkeley: University of California Press.

Körber, A. (2015) Historical Consciousness, Historical Competencies - and Beyond?: Some conceptual development within German history didactics. Pedocs Open Access, Deutsches Institut für Internationale Pädagogische Forschung (DIPF) Informationszentrum (IZ) Bildung. Accessed 19 July 2021. www.pedocs.de/volltexte/2015/10811/pdf/Koerber_2015_Development_ German_History_Didactics.pdf.

Levstik, L.S., Gwynn Henderson, A. and Lee, Y. (2014) 'The beauty of other lives: Material culture as evidence of human ingenuity and agency'. The Social Studies, 105 (4), 184-92. https://doi.org/ 10.1080/00377996.2014.886987.

Marcus, A.S. and Levine, T.H. (2011) 'Knight at the museum: Learning history with museums'. The Social Studies, 102 (3), 104-9. https://doi.org/10.1080/00377996.2010.509374.

Marcus, A.S., Levine, T.H. and Grenier, R.S. (2012) 'How secondary history teachers use and think about museums: Current practices and untapped promise for promoting historical understanding'. Theory and Research in Social Education, 40 (1), 66-97. https://doi.org/10.1080/00933104.2012.649466.

McKernan, A. (2018) 'Affective practices and the prison visit: Learning at Port Arthur and the Cascades Female Factory'. History of Education Review, 47 (2), 131-42. https://doi.org/10.1108/ HER-11-2017-0023.

Noel, A.M. and Colopy, M.A. (2006) 'Making history field trips meaningful: Teachers' and site educators' perspectives on teaching materials'. Theory and Research in Social Education, 34 (4), 553-68. https://doi.org/10.1080/00933104.2006.10473321.

Persson, A. (2017) 'Lärartillvaro och historieundervisning: Innebörder av ett nytt uppdrag i de mätbara resultatens tid'. PhD thesis, Umeå University.

Rantatalo, P. (2002) 'Den resande eleven: Folkskolans skolreserörelse 1890-1940'. PhD thesis, Umeå university.

Rohlf, G. (2015) 'How to make field trips fun, educational and memorable: Balancing self-directed inquiry with structured learning'. The History Teacher, 48 (3), 517-28. Accessed 19 July 2021. https://scholarlycommons.pacific.edu/cop-facarticles/16.

Rüsen, J. (2017) Evidence and Meaning: A theory of historical studies. New York: Berghahn Books.

Skolverket (2017) Läroplan för grundskolan, förskoleklassen och fritidshemmet 2011: reviderad 2017. Stockholm: Skolverket.

Smith, L., Wetherell, M. and Campbell, G. (2018) 'Introduction: Affective heritage practices'. In L. Smith, M. Wetherell and G. Campbell (eds), Emotion, Affective Practices, and the Past in the Present. London: Routledge, 1-21.

Stolare, M. (2014) 'På tal om historieundervisning: Perspektiv på undervisning i historia på mellanstadiet'. Acta Didactica Norge, 8 (1), 1-19. https://doi.org/10.5617/adno.1101.

Tolia-Kelly, D.P., Waterton, E. and Watson, S. (eds) (2017) Heritage, Affect and Emotion: Politics, practices and infrastructures. London: Routledge.

Trofanenko, B. (2014) 'Affective emotions: The pedagogical challenges of knowing war'. Review of Education, Pedagogy, and Cultural Studies, 36 (1), 22-39. https://doi.org/10.1080/ 10714413.2014.866820.

Wetherell, M. (2012) Affect and Emotion: A new social science understanding. London: Sage.

Wilson, A. and Hollis, G. (2007) 'How do we get better at going on trips?'. Teaching History, 126, 22-7.

Winch, C. (2013) 'Curriculum design and epistemic ascent'. Journal of Philosophy of Education, 47 (1), 128-46. https://doi.org/10.1111/1467-9752.12006.

Witcomb, A. (2013) 'Understanding the role of affect in producing a pedagogy for history museums'. Museum Management and Curatorship, 28 (3), 255-71. https://doi.org/10.1080/09647 775.2013.807998.

Zachrich, L., Weller, A., Baron, C. and Bertram, C. (2020) 'Historical experiences: A framework for encountering complex historical sources'. History Education Research Journal, 17 (2), 243-75. https://doi.org/10.14324/HERJ.17.2.08. 